\title{
Surgical management of displaced adolescent Tillaux Fractures with the mini-open technique
}

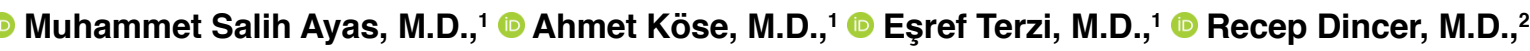

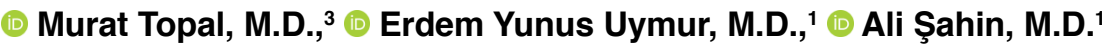

\author{
${ }^{1}$ Department of Orthopedics and Traumatology, Erzurum Regional Training and Research Hospital, Erzurum-Turkey \\ ${ }^{2}$ Department of Orthopedics and Traumatology, Süleyman Demirel University Faculty of Medicine, Isparta-Turkey \\ ${ }^{3}$ Department of Orthopedics and Traumatology, Kastamonu University Faculty of Medicine, Kastamonu-Turkey
}

\begin{abstract}
BACKGROUND: There is no consensus on the optimal treatment of Tillaux-Chaput fractures. The results of our cases treated with mini-open surgery (open reduction and internal fixation) concerning efficacy and complications, we aim to compare other procedures (open, percutaneous, and arthroscopy-assisted) with the literature data and to look for an answer to the question of whether the primary treatment can be mini-open surgery.
\end{abstract}

METHODS: Between the years 2014 and 2017, 22 of 30 patients with Tillaux-Chaput fractures were treated using mini-open surgery, open reduction and internal fixation with one cannulated screw. These cases were retrospectively examined concerning age, sex, side, surgery duration, complications, and American Orthopedic Foot and Ankle Score (AOFAS). Functional results were statistically evaluated 12 months after the injury. Follow-up included a clinical examination, imaging and AOFAS.

RESULTS: Of the patients, I 4 were male (63.6\%) and eight were female (36.4\%). The mean age of the patients was 13.8 years. The mean surgery duration was 21 minutes. All fractures healed after an average of 14 weeks. No complications were observed in any of the cases. The mean follow-up time was 24.7 months. The mean preoperative AOFAS score was 53.3 and the mean postoperative AOFAS score was 93.6, which was a statistically significant difference. At the last follow-up, the AOFAS score was perfect for all cases.

CONCLUSION: Contrary to what is stated in the literature, the mini-open surgical procedure has many advantages. The operation is very short and the risk of nerve injury is very low. This study showed that Tillaux-Chaput fractures could be safely and efficiently treated with mini-open surgery. We recommend mini-open surgery, complete anatomical reduction, and internal fixation for successful results.

Keywords: Adolescent; AOFAS; Chaput; mini-open surgery; surgical procedures; Tillaux.

\section{INTRODUCTION}

Isolated Salter-Harris type III fractures of the anterolateral distal tibial epiphysis are known as Tillaux-Chaput fractures. [1] These injuries are generally seen in adolescents 12 to 14 years of age. ${ }^{[2]}$ Triplane and Tillaux fractures consist of a multiplanar fracture pattern resulting from supination external rotation and compression stress. ${ }^{[3]}$ Since these fractures typically occur after tibial growth has concluded, they rarely result in growth arrest. ${ }^{[4-6]}$
These fractures may lead to light swelling, deformity, and pain and may occur due to a simple ankle sprain or a severe trauma. ${ }^{[7]}$ Although it is possible to identify Tillaux-Chaput fractures using $x$-ray, CT is often used to determine the number of broken fragments and the amount of displacement, ${ }^{[8,9]}$ All of these fractures are intraarticular in nature; thus, there is a risk of associated degenerative osteoarthritis, joint stiffness, and persistent pain. To reduce the specified long-term complications, surgical treatment is indicated. Although a joint cascade less than $2 \mathrm{~mm}$ is acceptable, a full anatomic reduc-

Cite this article as: Ayas MS, Köse A, Terzi E, Dincer R, Topal M, Uymur EY, et al. Surgical management of displaced adolescent Tillaux Fractures with the mini-open technique. Ulus Travma Acil Cerrahi Derg 2021;27:109-114.

Address for correspondence: Muhammet Salih Ayas, M.D.

Erzurum Bölge Eğitim ve Araştırma Hastanesi, Ortopedi ve Travmatoloji Kliniği, Erzurum, Turkey

Tel: +90 442 - 4321000 E-mail: muhammetsalihayas@yahoo.com.tr

Ulus Travma Acil Cerrahi Derg 2021;27(I):109-114 DOI: 10.14744/tjtes.2020.44609 Submitted: 16.1 I.2019 Accepted: 23.03.2020 Online: 09.12.2020

Copyright 2021 Turkish Association of Trauma and Emergency Surgery 
tion is necessary for perfect results, ${ }^{[6,10-12]}$ Theoretically, there is a low risk of physis closure after surgery; however, this could not be confirmed by a post-operative study. ${ }^{[13-15]}$

A review of the current literature revealed various series of open, percutaneous, and arthroscopy-assisted surgical procedures, ${ }^{[1,16,17]}$ but no consensus regarding the management of these fractures. In the present study, the results of our cases treated with mini-open surgery (open reduction and internal fixation); concerning efficacy and complications to compare other procedures (open, percutaneous, and arthroscopy-assisted) with the literature data and to look for an answer to the question of whether the primary treatment can be a mini-open surgery.

Level of Evidence: Level IV

\section{MATERIALS AND METHODS}

\section{Patients and Methods}

From 2014 to 2017, II0 patients arrived at the clinic or emergency service due to a distal tibia fracture. These cases were reviewed retrospectively and diagnoses were made according to clinical and radiological criteria.

Inclusion criteria were as follows: a cascade of at least $2 \mathrm{~mm}$ on the distal tibia joint surface, a broken fragment diameter of more than $5 \mathrm{~mm}$, and a follow-up duration of 12 months. Exclusion criteria included: bilateral, triplane, or pathological fractures, a joint cascade of less than $2 \mathrm{~mm}$, a fragment diameter of less than $5 \mathrm{~mm}$, the presence of an accompanying ipsilateral fracture, fractures with soft tissue defects, open fractures, and joint degeneration.

After evaluation, 22 of the 30 cases with Tillaux-Chaput fractures were determined to fit the inclusion criteria. The clinical and radiological data of these patients were reviewed retrospectively. For the data to be homogenous, the 12-month clinical data of the patients were evaluated statistically. To prevent bias, clinical and radiological evaluation of each case was performed blindly by a surgeon outside the surgical team.

The data were evaluated concerning age, sex, injury side, type of trauma, surgery duration, follow-up time, radiological healing time, preoperative and postoperative complications, American Orthopedic Foot and Ankle Score (AOFAS) and postoperative joint range of motion (Table I).

Of the 22 included patients, 14 were male (63.6\%), and eight were female $(36.4 \%)$. The mean age of the patients was 13.8 years (range 10-16 years). The trauma resulted from a sprain during exercise in 10 patients (46\%), a traffic accident in four patients (18\%), and a fall from a height in eight patients (36\%). The left ankle was affected in II (50\%) cases and the right ankle in I I (50\%) cases.
Approval was obtained from the institutional review board of our hospital for this study. Written consent was obtained from all patients and their families. All operations were performed by different surgeons of the same surgical team who were unaware of the measurement results made during this study.

\section{Surgical Technique}

All surgeries were performed with pneumatic tourniquet control applied to the extremity of the injured side. The operation was initiated with a $3 \mathrm{~cm}$ mini-surgical incision anterolateral from the fibula to the lateral surface of the peroneus tertius. To protect the superficial branch of the peroneal nerve from neurological damage, it was explored and protected. Upon reaching the joint, it was washed to remove possible mini joint parts that may have fallen onto the joint and remove fracture hematoma. Cartilage structures were examined to determine possible additional injuries. The periosteum and soft tissues were removed between the fractured fragments. The integrity of the anterior lower tibiofibular ligament was evaluated, and its integrity was confirmed. After anatomical reduction was ensured, two K-wires ( $1.0 \mathrm{~mm}$ in diameter) were placed perpendicular, parallel to the epiphysis and the plafond. C-arm radiographic fluoroscopy was used to confirm the ideal screw length and position. One cannulated screw (3.5-4.5 $\mathrm{mm}$ in diameter) was then secured over the K-wire guide. After the joint was washed again, the incision was closed with absorbable sutures, and the leg was splinted (Fig. I).

\section{Management and Rehabilitation After Surgery}

After the subjective complaints of the postoperative patients passed, finger movements were started passively-active. At the end of the second week after surgery, the splint was removed, and range of motion exercises for the ankle was added to the
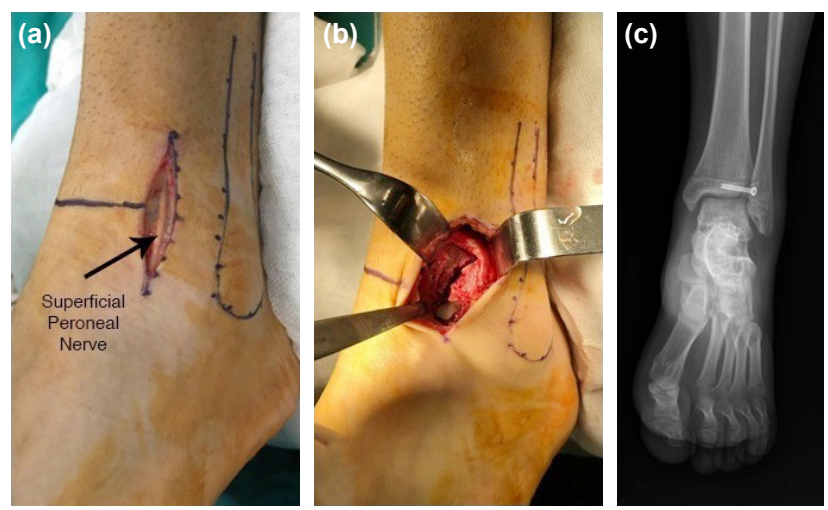

Figure 1. A 14-year-old male patient (case 8) presented with swelling and pain in his left ankle after a traffic accident. There was no sing of soft tissue injury in physical examination. Radiography and computed tomography were evaluated. A simple Tillaux-Chaput fracture with a displacement of $10 \mathrm{~mm}$ was observed on the left ankle. (a, b) A mini-open surgical procedure was performed through anterolateral ankle under regional anesthesia, and open reduction and internal fixation was achieved with a $3.5 \mathrm{~mm}$ cannulated screw. (c) Postoperative radiographic examination showed anatomical joint line. 


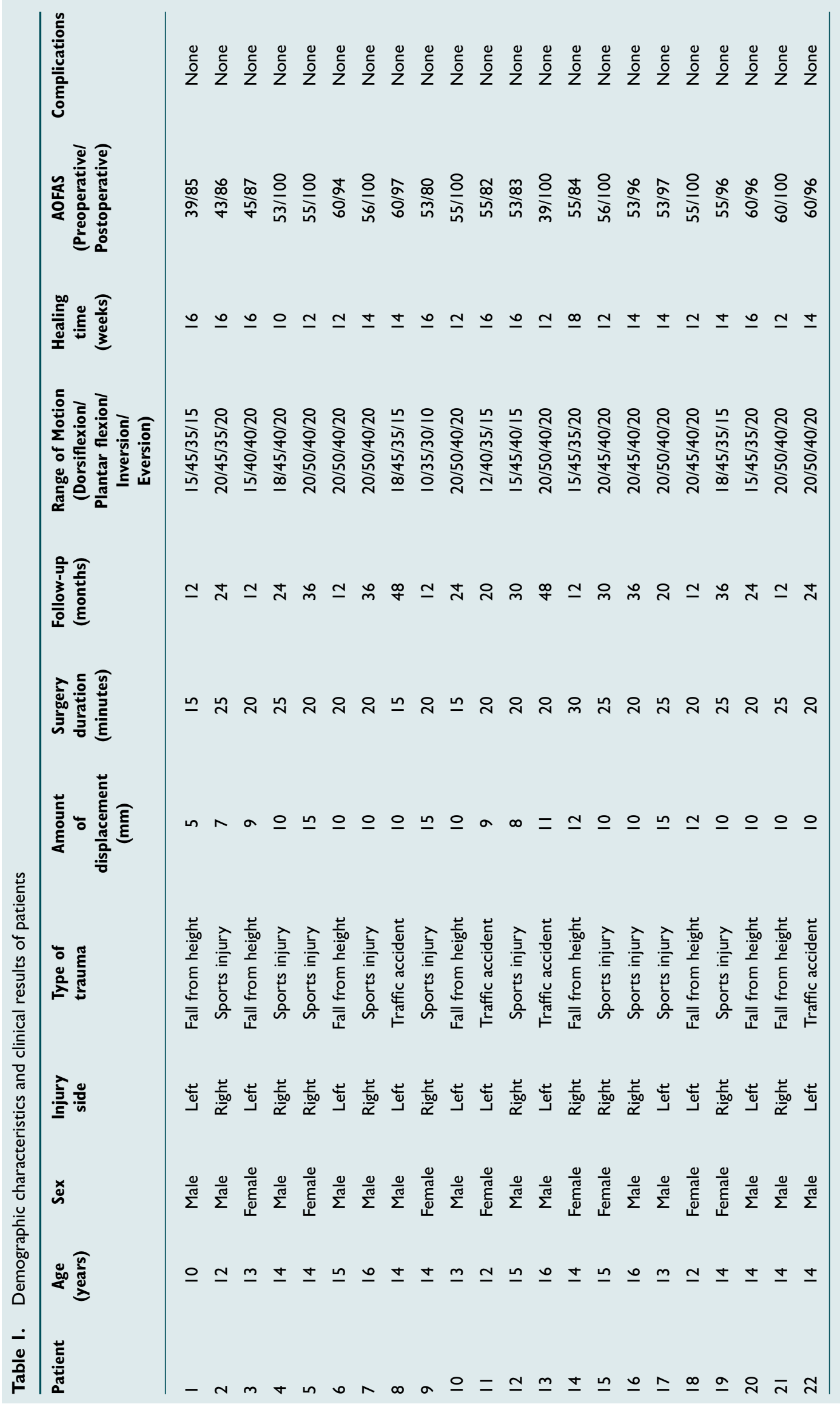


protocol. Applying partial load was allowed at the end of week four. Once the healing of the fractures was confirmed radiographically, the patients were allowed to apply their full weight and mobilization to the joint. All patients underwent radiography in the $2^{\text {nd }}, 6^{\text {th }}$, and $12^{\text {th }}$ weeks and the $6^{\text {th }}$ and $12^{\text {th }}$ months.

\section{Postoperative Follow-up and Evaluation Criteria}

All patients were examined postoperatively in the 6 th and $12^{\text {th }}$ week and $12^{\text {th }}$ month. The follow-ups included clinical examinations, imaging results, and AOFAS. Follow-up examinations were continued until patients were satisfied with the outcome or until they were lost to follow-up. The clinical symptoms were evaluated by AOFAS during the $12^{\text {th }}$-month follow-up. Pain scores were 40 points, joint functions were 50 points, and alignment was 10 points. A score of $90-100$ was classified as perfect, $80-89$ as good, $70-79$ as fair, and $<70$ as poor-bad. ${ }^{[16]}$

\section{Statistical Analysis}

All data were analyzed using the SPSS 22.0 statistical software program. Descriptive statistics of the evaluation results were given as a number (n) and percentage (\%) for categorical variables and mean (mean), standard deviation (SD), minimum (min) and maximum $(\max )$ values for numerical variables. The Kolmogorov-Smirnov test was used to evaluate the conformity of measurement data to a normal distribution. The Student's t-test was used to compare the data that fit the normal distribution and Mann-Whitney $U$ and Kruskal-Wallis variance analyses were used to analyze the data that did not fit the normal distribution. $\mathrm{P}<0.05$ was considered statistically significant.

\section{RESULTS}

Data from 22 patients fitting the inclusion criteria were examined. The mean preoperative clinical evaluation of AOFAS was 53 (range 39-60). Characteristics and clinical analysis results of the patients are given in Table $\mathrm{I}$.

The mean surgery duration was 21 minutes (range 15-30). All cases healed without any vascular, nerve, or tendon injury. All patients were followed-up after surgery for at least 12 months (range 12-48, mean 24.7). All fractures healed as confirmed by radiography after an average of 14 weeks (range 10-18) and all patients were healed completely at their last follow-up visit. Patients had normal ankle function, were able to do regular activities, and had no pain. In follow-up radiography, none of the patients had a refracture, a displacement in the fracture, or a step in the fracture line (Fig. 2).

Of all patients, four requested the removal of the implants despite having no subjective complaints. The earliest implant removal occurred after one year. Follow-up of these patients revealed no complications.

The mean postoperative AOFAS score was 93.6 (range 80$100)$, which was higher than the mean preoperative score of 53.3 (range 39-60) and the difference was statistically sig-
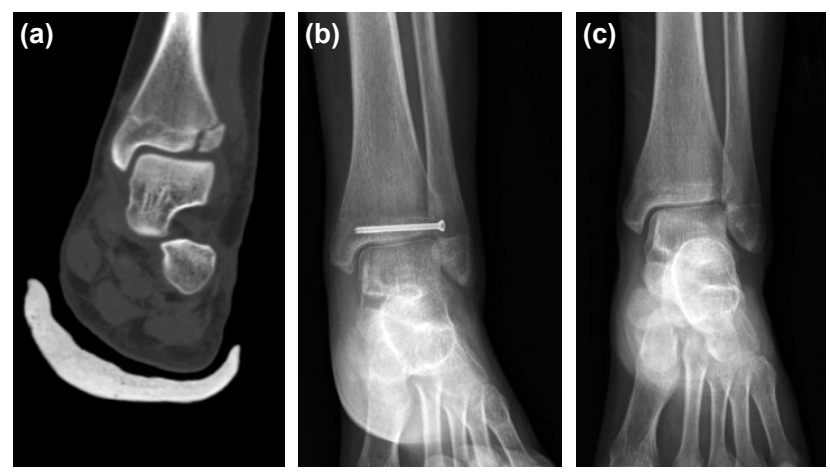

Figure 2. A 11-year-old female patient (case 11) presented with swelling and pain in his left ankle after a traffic accident. (a) Radiography and computed tomography were evaluated. Tillaux-Chaput fracture with a displacement of $9 \mathrm{~mm}$ was observed on the left ankle. (b, c) In the postoperative follow-up, the patient who did not have any complaints at the end of the first year wanted the implant removed. Postoperative radiographic showed bone healing and anatomical joint line.

nificant. The postoperative AOFAS was perfect for all cases according to the ankle-hindfoot scale score (Table I).

\section{DISCUSSION}

All cases in this study were treated using mini-open surgery, open reduction and internal fixation. The current study showed that the mini-open surgical procedure has many advantages, including minimal incision and dissection. The incision is not bigger than $3 \mathrm{~cm}$, which is the total size of the incisions made for arthroscopic portals and screws. The technique also does not require extensive surgical dissection. The superficial peroneal nerve is explored, and there is no risk of injury. This technique allows a direct look into the joint and the removal of mini fragments. The removal of the soft tissues that interpose into the fracture line is facilitated and a full anatomic reduction is enabled, minimalizing the risk of nonunion. Since the surgery is performed with the aid of a tourniquet, bleeding is almost non-existent. The surgical duration is very short and no short or long-term complications have been observed postoperatively.

Tiefenboeck et al. ${ }^{[3]}$ reported $90 \%$ excellent results in their study, which included seven patients undergoing open surgical internal fixation. They reported limitation of motion in the ankle as a complication in one patient. They based their successful results on open surgery and immobilization for at least four weeks. In another series performed with open surgery, Kaya et al. ${ }^{[18]}$ followed 10 patients for an average of 54 months and found an excellent value of $\mathbf{9 9 . 3}$ on average in the AOFAS score. In general, it is consistent with these two studies. The main difference is that our study included a larger series and our rehabilitation program. We started rehabilitation early and did not see any functional limitations in the ankle movements. For more successful results, it may be helpful to remove the splint early. We recommend mini-open surgery, complete anatomical reduction and internal fixation for successful results. 
Zelenty et al.'s ${ }^{[13]}$ study, which included 65 patients (open reduction: 48 + percutaneous fixation: 17) comparing open and percutaneous fixation, complications, such as permanent pain, nerve damage and infection, were higher in the group treated with open surgery. Therefore, they suggested that the percutaneous technique should be considered as the first choice for patients scheduled for surgical treatment. All the patients in the current study were treated using mini-open surgery and no complications were observed. Since it is an open technique, the complications that arise from the percutaneous technique are eliminated. It especially minimizes the risk of possible superficial peroneal nerve injury. Since it is an open procedure, pain is a postoperative problem. However, mini-open surgical technique has a small surgical incision and is a respectful approach to soft tissue. Pain can be minimized with this technique.

Arthroscopic techniques are currently used for intraarticular fractures. When compared to open surgery for Tillaux-Chaput fractures, it has been argued that arthroscopic surgery has the advantages of less bleeding, fewer complications, and shorter healing times, which makes it a quicker technique. ${ }^{[16,19-22]}$ The largest series made with arthroscopic-assisted was made by Feng et al. ${ }^{[16]}$ In their retrospective study involving 19 patients, they reported excellent clinical and radiological results in their studies without any complications. They achieved full union in an average of $\mathbf{2 3 . 5}$ months. Fracture union times were much longer than the average of our study. The reason for this is that even if the joint is evaluated with the help of arthroscopy, in some cases, soft tissues may have intervened in the invisible part of the fracture line and the fracture union time may be prolonged because of this. When arthroscopy-assisted treatment results are compared to our study; due to the use of a tourniquet with the mini-open surgical technique, we found almost no bleeding. There was no complication in any case, and there were no problems concerning wound healing. In our study, a similar mean surgical time (2I minutes) was documented with arthroscopic-assisted procedures. ${ }^{[16]}$

While the advantages of arthroscopy in intra-articular fractures are undeniable, ${ }^{[16,21,22]}$ we contend that it cannot show the superior line in the fracture area and is insufficient for removing interposed tissues on the physis line. These drawbacks may lead to insufficient reduction and problems regarding the physis. ${ }^{[23]}$ Another point to consider that the total size of incisions for arthroscopic portals and screws, approximately $3 \mathrm{~cm}$ long, is equivalent to the skin incision used in the mini-open surgical procedure. Also, suitable arthroscope scopes for patients may not always be available in the operating room. Lastly, there is a possibility that the fluid used during arthroscopy may be extravasated, which may increase postoperative pain, cause compartment syndrome, and make rehabilitation more difficult. These possible disadvantages and complications are not very likely to occur with mini-open surgery. We are aware of the advantages of arthroscopic-assisted surgery, but current literature data and our study show that mini-open surgery can still be considered a priority treatment.
Studies suggesting open reduction and internal fixation advocate immobilization for at least four weeks postoperatively. [3,18] The current study's results were similar, with two weeks of immobilization applied during patient follow-up based upon the patient's age concerning rehabilitation and the status of the fracture. In addition, we wanted to prevent Achilles tendon and joint contracture during the follow-up of immobilized intra-articular fractures, prevent reflex sympathetic dystrophy, and facilitate rehabilitation, ${ }^{[15,24]}$ In our opinion, early removal of the splint and the start of rehabilitation do not alter functional results in the long term, but it facilitates rehabilitation in the short term and may allow them to return to daily activities more easily.

There are some limitations to the current study, including the small case series, no long-term data, no comparison group, given that the surgeries were performed by more than one surgeon, and the retrospective design.

\section{Conclusion}

The localization and the displacement amount of Tillaux-Chaput fractures determine the surgical requirements. The current study showed that it is possible to achieve perfect clinical and radiological results with a mini-open surgery procedure. Contrary to what is stated in the literature, mini-open surgery has many advantages, including the very short duration of the procedure and the small incision size required, as well as the very low risk of nerve injury. The findings obtained in this study suggest that Tillaux-Chaput fractures can be safely and efficiently treated with mini-open surgery. As a result, intra-articular fractures require open surgery and fixation. The choice of open or mini-open surgery depends on the surgeon's experience.

Ethics Committee Approval: The Health Sciences University Erzurum Regional Training and Research Hospital ethics committee granted approval for this study (date: I I.02.2019, number: 37732058-5 |4.10).

Peer-review: Internally peer-reviewed.

Authorship Contributions: Concept: M.S.A., A.K., E.T., R.D., M.T., E.Y.U., A.Ş.; Design: M.S.A., A.K., E.T., R.D., M.T., E.Y.U., A.Ş.; Supervision: M.S.A., A.K., E.T., R.D., M.T., E.Y.U., A.Ş.; Resource: M.S.A., A.K., E.T., R.D., M.T., E.Y.U., A.Ş.; Materials: M.S.A., A.K., E.T., R.D., M.T., E.Y.U., A.Ş. Data: M.S.A., A.K., E.T., R.D., M.T., E.Y.U., A.Ş.; Analysis: M.S.A., A.K., E.T., R.D., M.T., E.Y.U., A.Ş.; Literature search: M.S.A., A.K., E.T., R.D., M.T., E.Y.U., A.Ş.; Writing: M.S.A., A.K., E.T., R.D., M.T., E.Y.U., A.Ş.; Critical revision: M.S.A., A.K., E.T., R.D., M.T., E.Y.U., A.Ş.

Conflict of Interest: None declared.

Financial Disclosure: The authors declared that this study has received no financial support.

\section{REFERENCES}

1. Koury SI, Stone CK, Harrell G, La Charité DD. Recognition and 
management of Tillaux fractures in adolescents. Pediatr Emerg Care 1999;15:37-9. [CrossRef]

2. Duchesneau S, Fallat LM. The Tillaux fracture. J Foot Ankle Surg 1996;35:127-89. [CrossRef]

3. Tiefenboeck TM, Binder H, Joestl J, Tiefenboeck MM, Boesmueller S, Krestan C, Schurz M. Displaced juvenile Tillaux fractures : Surgical treatment and outcome. Wien Klin Wochenschr 2017;129:169-75. [CrossRef]

4. Du P, Chen K, Patterson D, Ranade S. The pediatric ankle and foot: a review of common injuries in the pediatric athlete and their treatments. Ann Jt 2018;3:35. [CrossRef]

5. Prior CP, Harris PC. Fractures of the distal tibial physis. Orthop Trauma. Elsevier 2018;32:332-42. [CrossRef]

6. Crawford AH. Triplane and Tillaux fractures: is a $2 \mathrm{~mm}$ residual gap acceptable?.J Pediatr Orthop. 2012;32:S69-73. [CrossRef]

7. Ömeroğlu H. Basic principles of fracture treatment in children. Eklem Hastalik Cerrahisi 2018;29:52-7. [CrossRef]

8. Liporace FA, Yoon RS, Kubiak EN, Parisi DM, Koval KJ, Feldman DS, et al. Does adding computed tomography change the diagnosis and treatment of Tillaux and triplane pediatric ankle fractures? Orthopedics 2012;35:e208-12. [CrossRef]

9. Kose O, Yuksel HY, Guler F, Ege T. Isolated Adult Tillaux Fracture Associated With Volkmann Fracture-A Unique Combination of Injuries: Report of Two Cases and Review of the Literature. J Foot Ankle Surg 2016;55:1057-62. [CrossRef]

10. Horn BD, Crisci K, Krug M, Pizzutillo PD, MacEwen GD. Radiologic evaluation of juvenile tillaux fractures of the distal tibia. J Pediatr Orthop 2001;21:162-4. [CrossRef]

11. Lemburg SP, Lilienthal E, Heyer CM. Growth plate fractures of the distal tibia: is CT imaging necessary?. Arch Orthop Trauma Surg 2010;130:1411-7. [CrossRef]

12. Rapariz JM, Ocete G, González-Herranz P, López-Mondejar JA, Domenech J, Burgos J, et al. Distal tibial triplane fractures: long-term follow-up. J Pediatr Orthop 1996;16:113-8. [CrossRef]
13. Zelenty W, Yoon RS, Shabtai L, Choi P, Martin B, Horn D, et al. Percutaneous versus open reduction and fixation for Tillaux and triplane fractures: a multicenter cohort comparison study. J Pediatr Orthop B 2018;27:551-5. [CrossRef]

14. Leary JT, Handling M, Talerico M, Yong L, Bowe JA. Physeal fractures of the distal tibia: predictive factors of premature physeal closure and growth arrest. J Pediatr Orthop 2009;29:356-61. [CrossRef]

15. Olgun ZD, Maestre S. Management of Pediatric Ankle Fractures. Curr Rev Musculoskelet Med 2018;11:475-84. [CrossRef]

16. Feng SM, Sun QQ, Wang AG, Li CK. All-Inside" Arthroscopic Treatment of Tillaux-Chaput Fractures: Clinical Experience and Outcomes Analysis. J Foot Ankle Surg 2018;57:56-9. [CrossRef]

17. Choudhry IK, Wall EJ, Eismann EA, Crawford AH, Wilson L. Functional outcome analysis of triplane and tillaux fractures after closed reduction and percutaneous fixation. J Pediatr Orthop 2014;34:139-43.

18. Kaya A, Altay T, Ozturk H, Karapinar L. Open reduction and internal fixation in displaced juvenile Tillaux fractures. Injury 2007;38:201-5.

19. Panagopoulos A, van Niekerk L. Arthroscopic assisted reduction and fixation of a juvenile Tillaux fracture. Knee Surg Sports Traumatol Arthrosc 2007;15:415-7. [CrossRef]

20. Miller MD. Arthroscopically assisted reduction and fixation of an adult Tillaux fracture of the ankle. Arthroscopy 1997;13:117-9. [CrossRef]

21. Jennings MM, Lagaay P, Schuberth JM. Arthroscopic assisted fixation of juvenile intra-articular epiphyseal ankle fractures. J Foot Ankle Surg 2007;46:376-86. [CrossRef]

22. Chan KB, Lui TH. Role of Ankle Arthroscopy in Management of Acute Ankle Fracture. Arthroscopy 2016;32:2373-80. [CrossRef]

23. Barmada A, Gaynor T, Mubarak SJ. Premature physeal closure following distal tibia physeal fractures: a new radiographic predictor. J Pediatr Orthop 2003;23:733-9. [CrossRef]

24. Gourineni P, Gupta A. Medial joint space widening of the ankle in displaced Tillaux and Triplane fractures in children. J Orthop Trauma 2011;25:608-11. [CrossRef]

\section{ORIJINAL ÇALIŞMA - ÖZET}

\section{Adölasanlarda deplase Tillaux-Chaput kırıkların mini açık cerrahi ile yönetimi \\ Dr. Muhammet Salih Ayas, ${ }^{1}$ Dr. Ahmet Köse, ${ }^{1}$ Dr. Eşref Terzi, ${ }^{1}$ Dr. Recep Dincer, ${ }^{2}$ Dr. Murat Topal, ${ }^{3}$ Dr. Erdem Yunus Uymur, ${ }^{1}$ Dr. Ali Şahin ${ }^{1}$}

${ }^{1}$ Erzurum Bölge Eğitim ve Araştırma Hastanesi, Ortopedi ve Travmatoloji Kliniği, Erzurum

${ }^{2}$ Süleyman Demirel Üniversitesi Tıp Fakültesi, Ortopedi ve Travmatoloji Anabilim Dalı, Isparta

${ }^{3}$ Kastamonu Üniversitesi Tıp Fakültesi, Ortopedi ve Travmatoloji Anabilim Dalı, Kastamonu

AMAÇ: Tillaux-Chaput kırıkların optimal tedavisi tartışmalıdır. Bu çalışma ile, mini-açık cerrahi ile tedavi edilen olgularımızın sonuçları (açık redüksiyon ve internal fiksasyon); etkililik ve komplikasyonlar açısından, diğer prosedürleri (açık, perkütan ve artroskopi destekli) literatür verileri ile karşılaştırmak ve de birincil tedavinin mini açık cerrahi olup olmadı̆̆ı sorusuna bir cevap aramaktır.

GEREÇ VE YÖNTEM: 20I4-20I7 yılları arasında tedavi edilen 30 Tillaux-Chaput kırığı olgusunun 22'sine mini açık cerrahi prosedür ile açık redüksiyon ve internal fiksasyon uygulandı. Kırıkların hepsi bir adet kanüllü vida ile tespit edildi. Hastalar geriye dönük olarak yaş, cinsiyet, yön, operasyon süresi, komplikasyonlar ve AOFAS skoru incelendi. Fonksiyonel sonuçları yaralanma zamanından 12 ay sonra istatistiksel olarak değerlendirildi. Takipler; klinik muayene, elde edilen görüntüleme sonuçları ve AOFAS skoru ile yapıldı.

BULGULAR: Hastaların, I4'ü (\%63.6) erkek ve sekizi (\%36.4) kadındı. Hastaların yaş ortalaması I3.8 idi. Ortalama ameliyat süresi 2 I dakika idi. Tüm kırıklarda ortalama 14 haftada kaynama elde edildi. Olguların hiçbirinde komplikasyon görülmedi. Ortalama takip süresi 24.7 aydı. Ameliyat öncesi ortalama AOFAS skoru 53.3 puandı, ameliyat sonrası AOFAS skoru 93.6 puandı. Bu veriler arasındaki fark istatistiksel olarak anlamlıydı. Son takipte AOFAS skoru tüm olgular için mükemmeldi.

TARTIŞMA: Literatürde belirtilenin aksine mini açık cerrahi prosedürün birçok avantajı mevcuttur. Cerrahi süre kısadır. Sinir yaralanma riski çok düşüktür. Bu çalışma Tillaux-Chaput kırıklarının tedavisinin mini açık cerrahi prosedür ile güvenilir ve etkili bir şekilde yapılabileceğini göstermektedir. Başarılı sonuçlar için mini-açık cerrahi, tam anatomik redüksiyon ve internal fiksasyon öneriyoruz.

Anahtar sözcükler: AOFAS skoru; cerrahi işlemler; Chaput; ergen, mini açık cerrahi; Tillaux.

Ulus Travma Acil Cerrahi Derg 2021;27(1):109-1 I4 doi: 10.14744/tjtes.2020.44609 